\title{
Hypopigmented Mycosis Fungoides: Loss of Pigmentation Reflects Antitumor Immune Response in Young Patients
}

\author{
Amelia Martínez Villarreal ${ }^{1}$, Jennifer Gantchev ${ }^{1}$, François Lagacé ${ }^{2}$, Augustin Barolet ${ }^{2}$, \\ Denis Sasseville ${ }^{2}$ (D), Niels Ødum ${ }^{3}{ }^{(1)}$, Yann Vincent Charli-Joseph ${ }^{4,5}$, \\ Amparo Hernández Salazar ${ }^{4}$ and Ivan V. Litvinov 1,2,*(D) \\ 1 Division of Experimental Medicine, McGill University, Montreal, QC H4A3J1, Canada; \\ amelia.martinezvillarreal@mail.mcgill.ca (A.M.V.); jennifer.theoret@mail.mcgill.ca (J.G.) \\ 2 Division of Dermatology, McGill University, Montreal, QC H4A3J1, Canada; \\ francois.lagace@mail.mcgill.ca (F.L.); augustin.barolet@mail.mcgill.ca (A.B.); \\ denis.sasseville@mcgill.ca (D.S.) \\ 3 LEO Foundation Skin Immunology Research Center, Department of Immunology and Microbiology, \\ University of Copenhagen, DK-2200 Copenhagen, Denmark; ndum@sund.ku.dk \\ 4 Cutaneous Hematopathology Clinic, Dermatology Department, Instituto Nacional de Ciencias Médicas y \\ Nutrición Salvador Zubirán, Ciudad de México 14080, Mexico; ycjderm@gmail.com (Y.V.C-J.); \\ amton72@gmail.com (A.H.S.) \\ 5 Department of Dermatology, University of California San Francisco, San Francisco, CA 94115, USA \\ * Correspondence: ivan.litvinov@mcgill.ca; Tel.: +1-514-934-1934
}

Received: 21 May 2020; Accepted: 16 July 2020; Published: 22 July 2020

\begin{abstract}
Hypopigmented mycosis fungoides (HMF) is a form of cutaneous T-cell lymphoma (CTCL), a heterogeneous group of extranodal non-Hodgkin's lymphomas. HMF has a unique set of defining features that include light colored to achromic lesions, a predilection for darker skin phototypes, an early onset of disease, and predominance of $\mathrm{CD}^{+} \mathrm{T}$-cells, among others. In the current review, we detail the known pathways of molecular pathogenesis for this lymphoma and posit that an active Th1/cytotoxic antitumor immune response in part explains why this variant is primarily seen in children/adolescents and young adults, who do not exhibit signs of immunosenescence. As a result of this potent cytotoxic response, HMF patients experience mostly favorable overall prognosis, while hypopigmentation may in fact represent a useful surrogate marker of cytotoxic immunity targeting the malignant cells. Understanding the molecular processes behind the specific features that define HMF may lead to improved diagnostic accuracy, personalized prognosis by risk stratification, and improved management of HMF. Moreover, improving our knowledge of HMF may aid our further understanding of other cutaneous lymphomas.
\end{abstract}

Keywords: mycosis fungoides; cutaneous T-cell lymphomas; hypopigmentation; hypopigmented mycosis fungoides; Th1; antitumor immune response; cytotoxic cells; immunosurveillance; immunoediting

\section{Introduction}

Mycosis fungoides (MF) is a form of cutaneous T-cell lymphoma (CTCL), a heterogeneous group of extranodal non-Hodgkin's lymphomas characterized by the expansion of monoclonal T-cells involving the skin [1-3]. MF and the leukemic disease Sézary syndrome (SS) are the two most commonly recognized forms of CTCL and account for approximately $53 \%$ of all CTCL cases [4,5]. Within MF, there are several variants, including, but not limited to, conventional Alibert-Bazin, granulomatous, granulomatous slack skin, poikilodermatous/poikiloderma vasculare atrophicans, pagetoid reticulosis, folliculotropic, 
syringotropic, and hypopigmented MF [6,7]. Hypopigmented mycosis fungoides (HMF) is an important variant of MF to investigate, due to its high incidence in pediatric and juvenile populations, as well as its favorable prognosis when compared to the conventional Alibert-Bazin MF [8].

\section{Characteristics of Hypopigmented Mycosis Fungoides}

HMF is characterized by light colored to achromic lesions, mostly patches or thin plaques (Figure 1) [8,9]. Nonetheless, tumors have been reported in rare patients [10,11]. Currently, the most accepted hypothesis explains that the light colored to achromic skin lymphoma is due to damaged and reduced number of melanocytes in addition to abnormal melanogenesis [8,12].
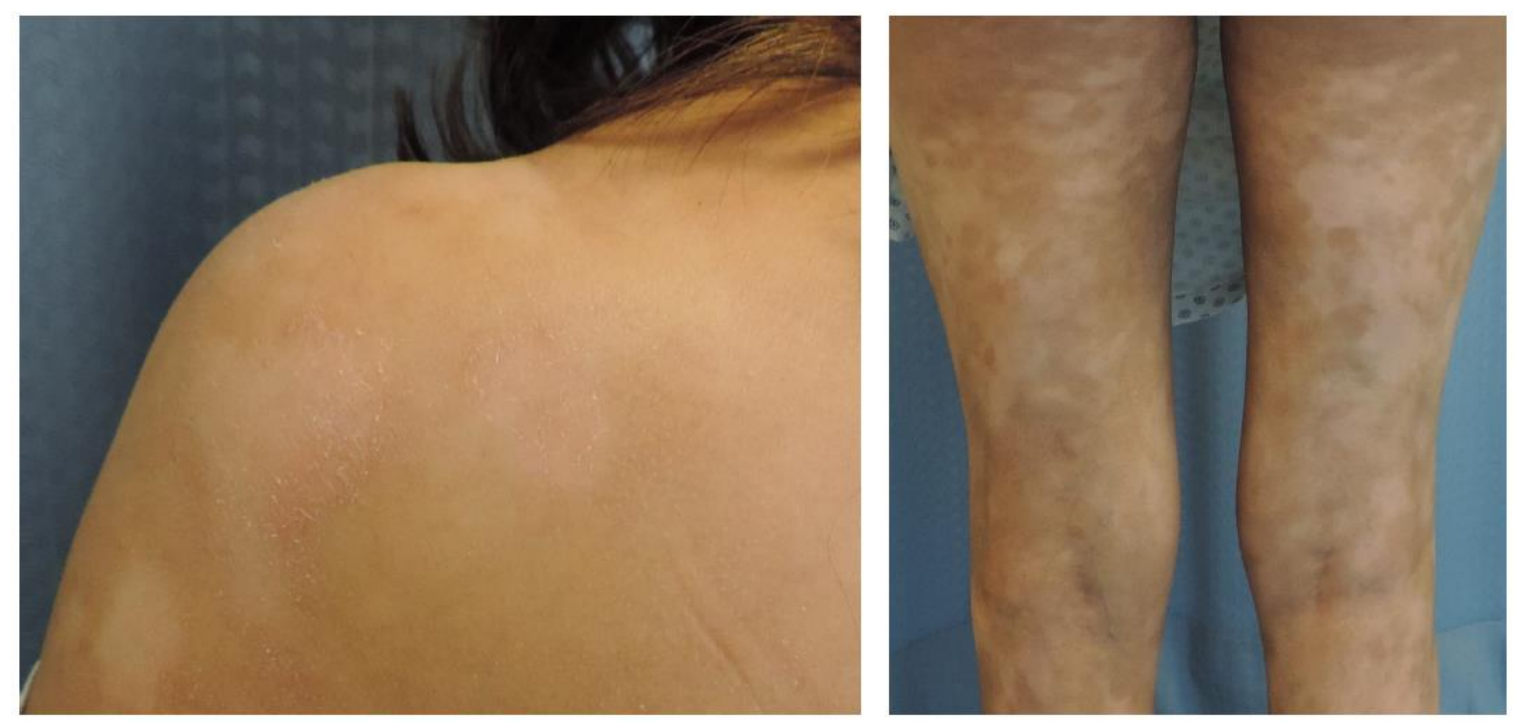

Figure 1. Clinical images of hypopigmented mycosis fungoides (HMF).

HMF lesions are commonly found in non-sun exposed areas, predominantly on the extremities, the buttocks, and the trunk in a bathing-suit pattern $[7,13]$. There are a few documented cases of HMF with facial involvement [9]. The number, size, and shape of the lesions are variable, with some case reports ranging from a single lesion [14] to lesions covering large body surface areas, with poorly circumscribed or irregular shapes. Lesions are occasionally accompanied by pruritus, sensitivity, telangiectasia, and/or atrophy. In rare cases, systemic signs, such as lymphadenopathy, are present $[8,9,15]$. In this review, we classified case reports/case series of HMF cases based on whether they took the Fitzpatrick skin phototype classification into account (Supplementary Materials Table S1) or not (Supplementary Materials Table S2). In addition, we highlighted key demographic features of the disease.

HMF is more prevalent in populations with darker skin phototypes (Fitzpatrick phototypes IV-VI), including African-American, South Asian, Middle Eastern, and Hispanic individuals, where the hypopigmented skin lesions are more clinically apparent $[4,9]$. Nevertheless, there are reports of HMF in Caucasian populations as well [16]. There is a debate whether a female predominance exists [17]; however, most publications agree that the female to male ratio is approximately 1:1 [18].

HMF has an earlier age of onset than the conventional MF. Conventional Alibert-Bazin MF commonly appears in older patients with a median age between 55 and 60 years at diagnosis [7]. In contrast, the age of onset for HMF is much earlier, with several cases reported in pediatric, adolescent, and early adulthood populations. The disease has been reported in children as young as 6 months of age [19].

HMF has a better prognosis than the conventional MF. Stratification and clinical staging remain the best prognostic factors for conventional Alibert-Bazin MF [1], which are determined by the skin disease burden and extracutaneous involvement. Conventional MF diagnosed at an early stage (IA-IIA) often has an indolent course and slow progression [4], whereas the life expectancy for advanced stages $(\geq \mathrm{IIB})$ ranges between 3.2 and 9.9 years [2]. HMF, in general, has an excellent prognosis and the majority of 
patients are diagnosed at an early stage (IA-IB) of the disease. They present with an indolent form and they rarely progress beyond stage IB [8].

Like in other forms of MF, the treatment of HMF depends on the clinical stage at presentation. In most cases, a skin-directed therapy is used. Phototherapy (e.g., narrowband ultraviolet B or in select cases, ultraviolet A1) and photochemotherapy (e.g., psoralen and ultraviolet A (PUVA)) are the treatments most commonly used first-line together with topical products (e.g., topical steroids, retinoids, imiquimod, or nitrogen mustard). Photochemotherapy, also known as PUVA, involves the ingestion of 8-methoxypsoralen about 1.5-2 h prior to an exposure to ultraviolet A (UVA) radiation (320-400 nm). In younger patients with folliculotropic HMF, UVA1 (340-400 nm) treatment, if available, may be a safer alternative to PUVA. Photochemotherapy induces DNA damage, suppresses keratinocyte cytokine production, reduces the number of Langerhans cells, and induces apoptosis on malignant cells. Narrowband ultraviolet B light (NUVB; $311 \mathrm{~nm}$ ) is the first-line method of treatment of HMF, where it works by suppressing malignant cell proliferation through increased keratinocyte cytokine production and through inhibition by antigen-presenting cells $[7,8]$. Often, a course of phototherapy that lasts several months to a year, together with the aforementioned topical products, enables dermatologists to achieve disease control and induce a long-lasting remission. Very rarely, in aggressive disease, a total skin electron beam therapy (TSEBT) may be considered [7]. However, since HMF patients are usually adolescents/young adults, most physicians try other treatment options before resorting to radiation.

Regarding the topical products, topical steroids are most commonly used early in MF. Steroids modify lymphocyte adhesion to the endothelium, downregulate Nuclear factor- $\mathrm{kB}(\mathrm{NF}-\mathrm{\kappa B})$ and Activator protein-1 (AP-1), decrease cytokine and growth factor production, and induce apoptosis. Topical nitrogen mustard is an alkylating agent that induces DNA damage and may affect keratinocyte-Langerhans cell interactions. Retinoids and bexarotene specifically and selectively bind to retinoid receptors (Retinoid X Receptor or RXR in the case of bexarotene), which affects cell differentiation and induces apoptosis. Imiquimod activates Toll-Like Receptor-7 (TLR7) receptor signaling, leading to local interferon- $\alpha$ (IFN- $\alpha$ ) and interferon- $\beta$ (IFN- $\beta$ ) production, which augments antitumor immune response. Fortunately, HMF patients do not require systemic therapy. Some dermatologists may offer these patients a systemic retinoid (e.g., alitretinoin, isotretinoin, or bexarotene) to make the phototherapy more effective. Despite the long-term skin-directed treatments and the indolent behavior of HMF, recurrence is often reported, which may occur after months or years of total remission [8].

HMF has similar histopathological features to other MF variants. Lesions show epidermotropism of single or clusters of malignant T-cells forming Pautrier's microabscesses, surrounding Langerhans cells. The malignant cells are haloed, small to medium in size, and have an irregular and hyperconvoluted nucleus [4]. Focal parakeratosis and spongiosis are common in HMF. A striking epidermotropism and a predominance of clonal malignant $\mathrm{CD} 8^{+}$T-cells are the two common histologic features of HMF, which other MF variants do not exhibit as often $[6,8]$.

\section{Immunopathogenesis of Alibert-Bazin and Hypopigmented Mycosis Fungoides}

The pathogenesis of MF and HMF is incompletely understood and several theories have been proposed, highlighting the importance of external triggers, including Staphylococcus aureus toxins, and the activation/deregulation of JAK-STAT, NOTCH, MAPK, and other signaling pathways [3,20-24]. It is believed that malignant T-cells in MF arise from mature resident CD45RO $\mathrm{R}^{+} \mathrm{T}$-cells engaged in normal cutaneous immune surveillance [25]. Cutaneous immune surveillance maintains homeostasis between the host and the environment. However, when this homeostasis is challenged by environmental or pathogen-driven damage to the skin, cellular injury, or stress, keratinocytes respond by releasing pro-inflammatory cytokines. These cytokines may have two consequences.

The first consequence results in the mobilization of the innate immune system. It is manifested by the recruitment of several immune cell types, such as dendritic cells (DCs), mast cells, and macrophages. These newly recruited immune cells initiate and maintain cutaneous inflammation, facilitated by the recognition of pathogen patterns, identified by their receptors such as toll-like receptors (TLRs). 
This recognition activates the NF- $\mathrm{BB}$ pathway within these immune cells, which results in direct effects on pathogens. This process constitutes the innate immune surveillance occurring in the skin $[25,26]$.

The link between the innate and adaptive immune responses is facilitated by the activation of the NF-KB pathway in antigen-presenting cells (APCs). The specialized APCs in the epidermis are the Langerhans cells and their dermal counterparts are the dermal DCs. Research indicates that Langerhans cells may be the source of sustained antigen stimulation, resulting in a chronic inflammatory response in the skin, which is characteristic of MF. The activation of the NF- $\mathrm{KB}$ pathway triggers APCs to migrate toward the skin-draining lymph nodes. Once in the lymph nodes, APCs encounter naive T-cells and activate them [25]. These newly active T-cells are antigen-specific cells and express cutaneous lymphocyte antigen (CLA) as well as CC chemokine receptor 4 (CCR4), which induce a skin-targeted migration via chemotaxis.

The second consequence of primary cytokine release by the keratinocytes directly results in the recruitment of adaptive immune cells, mostly active T-cells, in the skin. As such, the upregulation of adhesion molecules in the dermal vessels is observed. The adhesion molecules E-selectin and CC chemokine ligand 17 (CCL17) are complementary to the CLA and CCR4 receptors expressed on the newly activated T-cells, respectively. Specific recognition of these ligands allows active T-cells to tether and roll along the endothelium and extravasate into the dermis. Once in the dermis, $\mathrm{T}$ cells produce signaling molecules and cytokines. These signaling molecules and cytokines can have an effector function (i.e., elimination of infection) or can mediate an inflammatory response [27].

Once homeostasis is reestablished, the former activated T-cells should be eliminated; however, monoclonal T-cells in MF continue to proliferate [27]. Such proliferation is driven by inappropriate activation of STAT signaling pathways, upregulation of oncogenic miRNAs, activation of Thymocyte Selection-Associated HMG Box (TOX) oncogene, production of autocrine growth factors, and exposure to $S$. aureus enterotoxins [28-40]. Uncontrolled proliferation of active malignant T-cells (initiated by inappropriate and prolonged antigen stimulation) in the skin eventually dysregulates the normal host immune system, consequently affecting the antitumor immune response as well $[25,28]$.

\section{Cancer Immunoediting in Mycosis Fungoides}

Uncontrolled monoclonal proliferation of active malignant T-cells homing to the skin elicits an antitumor immune response in MF [28,41]. Disease progression along with specific cellular and cytokine profiles can be associated with one of the three phases of cancer immunoediting: elimination, equilibrium, and escape (Figure 2). During the elimination phase, the immune system is able to control the proliferation of the malignant T-cells; hence, the malignant T-cells remain occult/incognito (Figure 2A) [42]. It is worth mentioning that no specific antigens or immunogenic characteristics of malignant T-cells in MF have been discovered thus far [23,24,41].

Progressively, the malignant cells and the immune system advance into the equilibrium phase of cancer immunoediting (Figure 2B). This phase is a period of latency characterized by the balance between surviving and dying tumor cells, sustained by the immune response [43]. Evidence of this steady state in MF includes high numbers of tumor infiltrating CD8 ${ }^{+}$T-cells and a Th1 cytokine profile in lesional skin. The equilibrium phase often corresponds to clinical stages IA-B and IIA in MF $[41,42,44,45]$. Recent research suggests that HMF remains in the equilibrium phase of the cancer immunoediting process. Research regarding cytotoxic molecules and cytokines secreted by neoplastic and/or infiltrating cells, along with the absence of infiltrating regulatory T-cells (Tregs), constitutes evidence that HMF has a better antitumor immune response, when compared to the conventional Alibert-Bazin MF.

In conventional MF, research suggests that infiltrating $\mathrm{CD} 8^{+}$cytotoxic T-lymphocytes have a major role in determining disease prognosis and antitumor immune response [46]. T-cell intracytoplasmic antigen 1 (TIA1) is a cytotoxic molecule constitutively expressed by $\mathrm{CD} 8^{+}$cytotoxic cells, either in their active or resting state [47]. It has been reported that, in HMF, malignant CD8 ${ }^{+}$lymphocytes are TIA1 positive $[16,17,48]$, whereas malignant CD8- lymphocytes are TIA1 negative [49]. However, given 
that $\mathrm{CD} 88^{+}$cells express TIA1 regardless of whether they are active or resting, this does not reflect an active antitumor immune response. On the other hand, tumor-infiltrating lymphocytes (TILs), that are part of the antitumor immune response, also express TIA1 along with a series of cytotoxic cytokines (e.g., granzyme B and granulysin) [50], suggesting an active antitumor immune response.

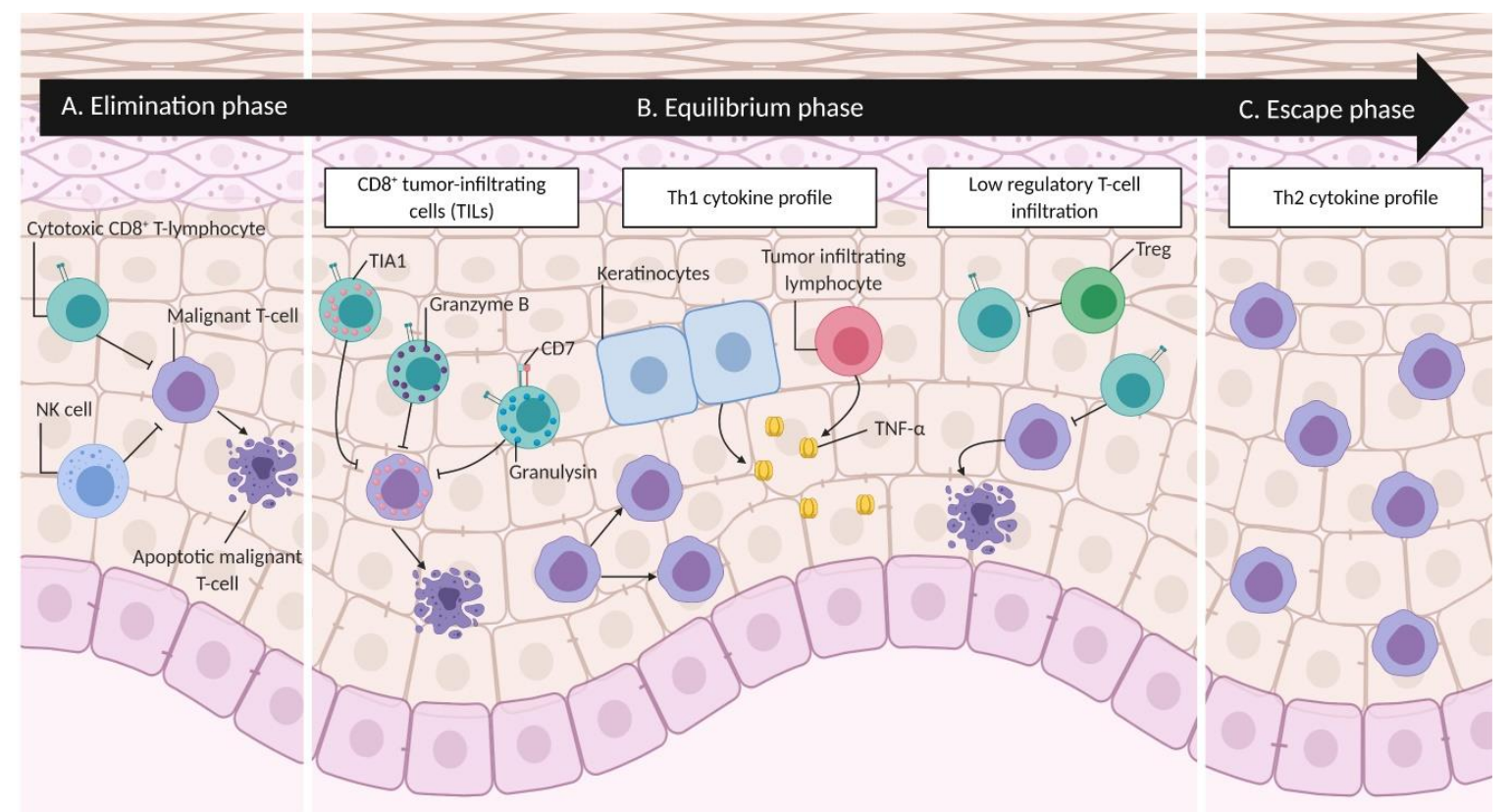

Figure 2. Cancer immunoediting in mycosis fungoides. Each phase of cancer immunoediting can be associated with specific cellular and cytokine profiles. In the elimination phase (A), the immune system, depicted here by cytotoxic CD8+ T-lymphocytes and Natural Killer (NK) cells, controls the proliferation of malignant T-cells, keeping them occult/incognito. Several evidences suggest that HMF remains in the equilibrium phase (B). Specifically, CD8+ tumor-infiltrating cells (TILs) secrete TIA1, granzyme B, and granulysin, which are cytotoxic granules that induce apoptosis in malignant T-cells. The production of Tumor Necrosis Factor- $\alpha$ TNF- $\alpha$ by keratinocytes and TILs induce an active antitumor immune response. A low level of regulatory T-cell (Treg) infiltration reported in HMF suggests that TILs are able to induce apoptosis in malignant T-cells. Finally, in the escape phase (C), a shift to Th2 cytokine profile allows malignant cells to overcome immune recognition and proliferate in the skin and beyond. Figure created with BioRender.com.

Another cytotoxic molecule produced by active CD8 ${ }^{+}$cytotoxic cells is granzyme B. Granzyme B is a serine protease which induces apoptosis on its target cells [51]. The expression of granzyme B in several HMF patient samples has been demonstrated on dermal TILs, but not in malignant epidermal lymphocytes. Malignant cells do not express granzyme B, providing a possible explanation to the lack of ulceration and necrosis in HMF patients, when compared with the other forms of MF [52]. Furthermore, granzyme B positivity in dermal TILs represents a plausible evidence of the antitumor immune response that is a characteristic feature in HMF.

An analysis of granulysin, an additional cytotoxic molecule, further confirms the active involvement of antitumor immune response in HMF patients. Granulysin is expressed by activated cytotoxic lymphocytes and NK cells [53]. A differential staining between malignant cells and TILs for granulysin has been reported. Malignant $\mathrm{CD} 8^{+} \mathrm{CD} 7^{-}$cells often stained negatively for granulysin, while $\mathrm{CD} 8^{+} \mathrm{CD} 7^{+}$TILs were positive for granulysin [50]. CD8 ${ }^{+}$along with granulysin positivity in TILs constitutes additional support for the robust antitumor immune response provided by cytotoxic $\mathrm{CD} 8^{+}$tumor-infiltrating lymphocytes.

In addition to $\mathrm{CD} 8^{+}$TILs, a Th1 cytokine profile secreted by keratinocytes and lymphocytes provides evidence of an active antitumor immune response in HMF patients. This Th1 cytokine profile 
maintains the equilibrium phase of cancer immunoediting [42]. Among the cytokines that comprise the Th1 phenotype, tumor necrosis factor- $\alpha$ (TNF- $\alpha$ ) has been extensively studied in HMF patients. High levels of TNF- $\alpha$ mRNA [54] and protein in HMF skin lesions [52] have been reported. Blocking this cytokine proves detrimental and promotes carcinogenesis and CTCL progression. Patients with hypopigmented T-cell dyscrasia, who receive TNF- $\alpha$ inhibitor (etanercept) treatment for rheumatoid arthritis, have been known to progress to HMF/conventional MF [55]. In summary, the same level of expression of TNF- $\alpha$ in hypopigmented T-cell dyscrasia and HMF suggests an active antitumor immune response. However, when this immune response is blocked, progression of carcinogenesis ensues.

The last evidence indicating that HMF has an active antitumor immune response, which maintains the equilibrium phase of cancer immunoediting, is provided by Tregs. It has been established that Tregs inhibit natural or therapeutic immune response against tumors and can be identified by their immunophenotype $\mathrm{CD}^{+} \mathrm{CD}^{+} 5^{+} \mathrm{FOXP3}^{+}$[43]. When compared to conventional MF, HMF presents a decreased ratio of $\mathrm{FOXP}^{+} / \mathrm{CD}^{+}$and $\mathrm{FOXP}^{+} / \mathrm{CD} 25^{+}$cells [50]. Knowing that Tregs inhibit antitumor immune responses, this decreased ratio suggests that tumor immune response is active in HMF more so than in conventional MF. How HMF patients maintain a controlled antitumor immune response has yet to be determined.

The final phase of cancer immunoediting, the escape phase, is enabled by the genomic instability of cancer cells, activation of oncogenes, downregulation of tumor suppressor genes, ectopic reactivation of developmental/cancer testis/meiosis genes, deregulation of JAK/STAT signaling, further upregulation of TOX, contribution of external disease triggers/promoters (e.g., S. aureus enterotoxins), and Darwinian pressure by the immune system [28,32,56-62] (Figure 2C). These factors, in part, provide malignant cells with an increased resistance to immunosurveillance and promote their proliferation $[43,63]$. This last phase in MF is characterized by a shift to a Th2 cytokine profile with the concomitant expression of pro-eosinophilic/immunosuppressive molecules (IL-4, IL-10, and IL-13) and additional molecules such as Fas ligand, among others. This shift contributes to the escape of cancer cells from immune recognition, allowing neoplastic cells to proliferate in the skin, forming thick plaques/tumors, and beyond lymph nodes, blood, and visceral organs. [42].

\section{Hypopigmentation as a Surrogate Marker of Antitumor Immune Response in MF}

Hypopigmentation in MF has been proposed to be a result of an immune response originating from neoplastic cells or reactive immune cells [12]. However, we hypothesize that hypopigmentation is caused mainly by the active antitumor immune response. Specifically, we hypothesize that the damage and alteration of melanocyte function and differentiation are results of reactive $\mathrm{CD} 8^{+}$cytotoxic T-lymphocytes mostly, rather than the neoplastic $\mathrm{CD}^{+}$cytotoxic T-lymphocytes. This cytotoxic activity of T lymphocytes in addition to secretion of toxic granzyme B, granulysin, and other molecules has been shown to impact two melanocyte activation pathways: the first is activated by basic fibroblast growth factor (bFGF) and the second is activated by the stem cell factor (SCF), (i.e., c-kit ligand) (Figure 3). Both factors are produced by keratinocytes and act in a paracrine fashion on melanocytes. Furthermore, a Th1 inflammatory environment rich in TNF- $\alpha$ likely further contributes to melanocyte damage (Figure 3).

Specifically, bFGF binds to fibroblast growth factor receptor (FGFR) expressed on melanocytes, initiating the Ras/MAP kinase signaling pathway, among others. Whereas SCF binds to the CD117 (i.e., c-kit) receptor on melanocytes, leading to the upregulation of the microphtalmia-associated transcription factor (MiTF) and other melanocyte-specific proteins. Both pathways result in melanocyte growth and survival $[12,64]$. When compared to normal skin and conventional MF samples, HMF has lower levels of expression of bFGF mRNA [54] and CD117, tyrosinase, MART-1/melan-A [12,65], gp100 [65], and MiTF [12] proteins. This decrease in mRNA and protein leads to pigment loss caused by fewer and damaged melanocytes, abnormal melanogenesis, and melanocyte apoptosis. The decreased levels of molecules involved in melanocyte development are independent of the predominant T-cell phenotype of the malignant cells, $\mathrm{CD}^{+}$or CD8 (Figure 3). 


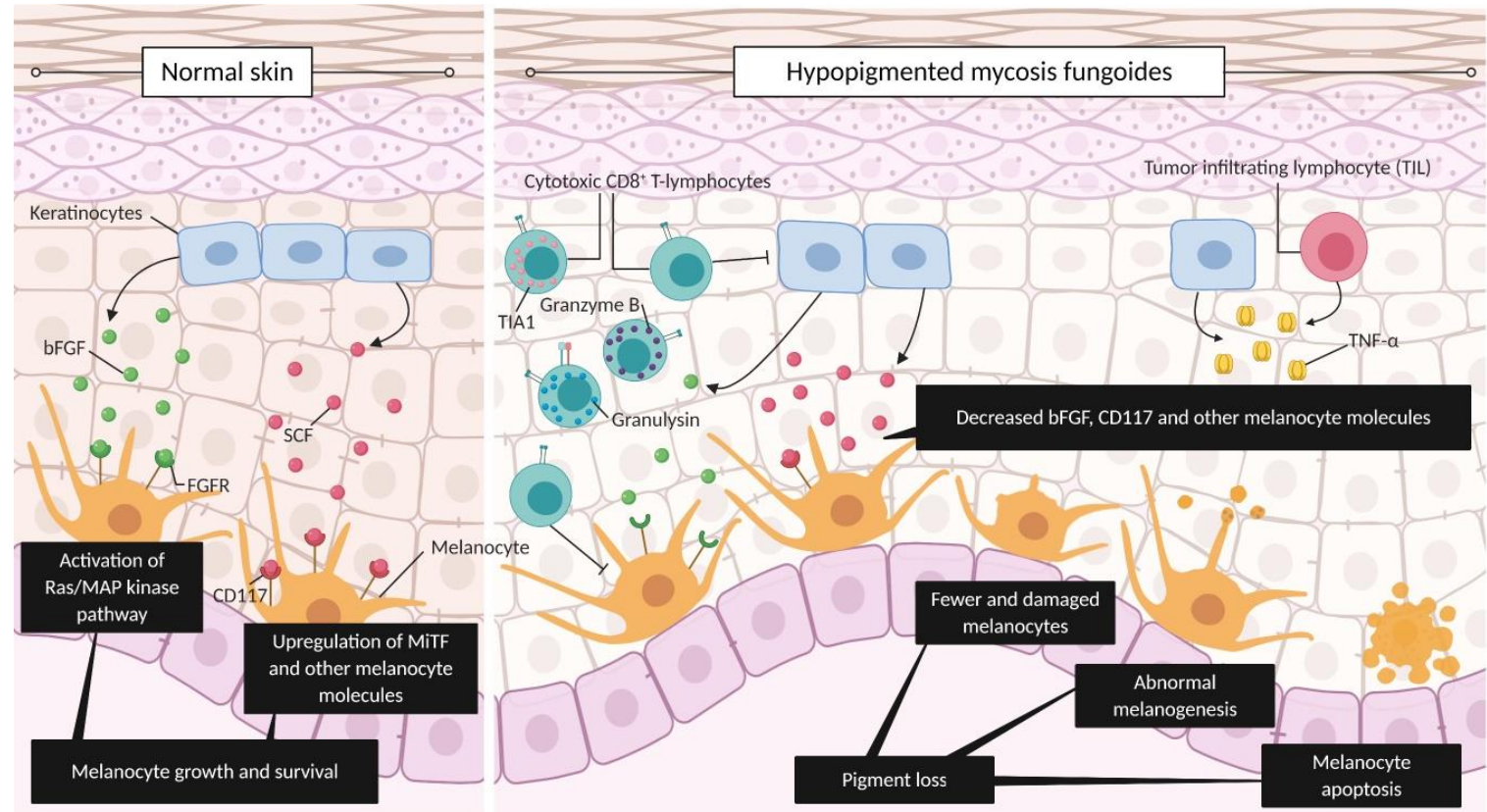

Figure 3. Hypopigmentation as a surrogate marker of antitumor immune response in mycosis fungoides (MF). In normal skin, keratinocytes produce basic fibroblast growth factor (bFGF) and stem cell factor (SCF). The binding of bFGF to FGF receptor (FGFR) in melanocytes activates the Ras/MAP kinase pathway, while the binding of SCF to its cognate receptor CD177 in melanocytes upregulates microphtalmia-associated transcription factor (MiTF) and additional melanocyte molecules, leading to melanogenesis. Both pathways lead to melanocyte growth and survival. In HMF, cytotoxic CD8+ lymphocytes, which act as part of the antitumor immune response, releasing granulysin and granzyme B, combined with the Th1 inflammatory response rich in TNF- $\alpha$, result in damage to keratinocytes and melanocytes. This damage to keratinocytes leads to a decreased level of the melanocyte molecules bFGF and CD117, among others. Without the signals needed for melanocyte growth/survival and in the presence of granzyme B, granulysin, and TNF- $\alpha$, HMF skin eventually has fewer and damaged melanocytes, abnormal melanogenesis, and apoptotic melanocytes. These features lead to the characteristic pigment loss of HMF. Figure created with BioRender.com.

Furthermore, a lower level of bFGF mRNA is associated with an increased level of TNF- $\alpha$ in stage I HMF patients [54]. This suggests that the decreased level of bFGF, which ultimately leads to pigment loss, is associated with an active Th1 cytokine profile, as shown by increased TNF- $\alpha$ expression.

Indeed, skin hypopigmentation or depigmentation is commonly associated with immune-related diseases (inflammatory dermatoses), such as Darier disease, lichen striatus, incontinentia pigmenti, pityriasis alba, and vitiligo, among others. The most accepted theory for vitiligo development is centered on an autoimmune response with $\mathrm{CD}^{+}$cytotoxic T-lymphocytes inducing melanocyte apoptosis. Specifically, infiltrating T-cells in vitiligo are associated with a Th1 phenotype, which induces melanocyte destruction via direct cytotoxicity and modulation of cytokine microenvironment [66]. Concomitant MF and vitiligo have been reported [67]; however, no studies have assessed whether vitiligo development impacts disease progression. Vitiligo patients also present a lower risk of skin cancer development, including melanoma [68].

Loss of pigmentation is one of the several immune-related adverse events in cancer patients under immunotherapy. These adverse events reflect an autoimmune attack on healthy tissue. Specifically, loss of pigmentation (depigmentation) has been reported in melanoma patients under immune checkpoint inhibitors and is thought to be a result of immune recognition of antigens on healthy melanocytes after breakage of immune privilege caused by malignant cell destruction $[69,70]$. In melanoma patients receiving either anti-programmed cell death-1 (PD-1) or cytotoxic T-lymphocyte antigen-4 (CTLA-4) therapies, the development of vitiligo-like lesions has been associated with a complete or partial 
response [71,72]. Moreover, tumor-infiltrating lymphocytes in these patients tend to skew towards $\mathrm{CD} 8^{+}$T-cell phenotype, along with increased production of interferon- $\gamma$ (IFN- $\gamma$ ) and TNF- $\alpha$ [70]. Reports of vitiligo-like lesions developed after immune checkpoint therapy in patients with cancers other than melanoma are less common [73].

Notably, following treatment, skin re-pigmentation is a common feature in HMF patients [12]. This suggests that the depletion of neoplastic cells, along with the consequent decline in the antitumor immune response, allows the re-establishment of melanosomes and melanocytes.

In summary, current literature suggests that hypopigmentation or depigmentation (as in vitiligo) may serve as a surrogate marker of an active immune response, specifically an antitumor immune response against malignant T-cells in MF, regardless of the T-cell phenotype. It has been established that skin cancers are highly immunogenic, reflecting the emergence of tumor-associated antigens, neoepitopes, and/or viral oncoproteins and immunosurveillance in this organ [69]. Consequently, the presence of hypopigmented patches and/or plaques in MF patients can be considered as a favorable prognostic marker.

\section{Clinical/Demographic Patient Characteristics as a Result of Antitumor Immune Response}

In addition, hypopigmentation, clinical/demographic features that are specific to HMF can be understood within the scope of active antitumor immunity found in these patients. Such clinical features include a younger age of onset and the overall good prognosis observed in HMF patients, regardless of the predominant phenotype of epidermotropic T-cells.

Childhood/juvenile MF is not common and it ranges from $2.7 \%$ to $16.6 \%$ of all MF cases. It is usually diagnosed in early stages with no lymph node involvement, and although recurrence is common, progression is unusual. Additionally, HMF is commonly overrepresented in pediatric case series [74-76], where patients maintain adequate immunity.

In general, pediatric, adolescent, and early adulthood populations have a robust immune system [77], whereas elderly patients' immune system is declining in a process termed immunosenescence. Immunosenescence is characterized by a lower number of naive T-cells in peripheral blood, reduction in diversity in the T-cell receptor (TCR) repertoire, and decreased diversity and integrity of $\mathrm{CD} 4^{+}$and $\mathrm{CD} 8^{+}$ cells, among others. The innate immune response is well preserved in elderly populations; however, adaptive immune response is susceptible to deleterious changes that may enable carcinogenesis [78]. Children, adolescents, and young adults do not have a declining adaptive immune response or decreased number of $\mathrm{CD} 8^{+}$cells, which are the features that may have an impact on antitumor immune response.

Normally, HMF has a better prognosis than conventional MF, regardless of the predominant cell phenotype of the epidermotropic neoplastic T-cells. Patients with a T-cell phenotype different than $\mathrm{CD}^{+}$represent only 7.3\% (Table 1) of all HMF cases reported (Tables S1 and S2). Almost all staged cases with an immunophenotype other than $\mathrm{CD}^{+}$present with early $(\leq \mathrm{IB})$ disease as well. In fact, the majority of cases that report progression of the disease still remain in the early stages (Table 1), thereby exhibiting an indolent course and slow progression [1,4]. Only two CD4 ${ }^{+}$patient deaths were reported, with accelerated progression $[79,80]$. In general, we consider that there are no critical differences regarding disease staging and prognosis between $\mathrm{CD} 8^{+} \mathrm{HMF}$ cases and HMF cases with other immunophenotypes. Thus, the literature indicates that the differential behavior of HMF compared to conventional MF is not caused directly by the predominant cell phenotype of the epidermotropic neoplastic T-cells.

HMF is characterized by hypopigmented lesions; however, it can be associated with lesions of other variants of MF or with different clinical presentations (i.e., mixed MF) (Table 2). Mixed MF represents $11.6 \%$ of all reported HMF cases (Tables S1 and S2). Among all the mixed MF cases reported, three were staged as $\geq$ II, two patients in stage IIA (early disease), and one patient in stage IVA. The latter was treated with chemotherapy and remained disease-free after 7 years of follow-up [76] (Table 2). In addition, one patient was reported to have large cell transformation (Table 2), which usually portends a worse prognosis; however, the patient responded well to phototherapy and topical steroids [81]. 
African-American and dark-skinned patients that presented with hypopigmented lesions had a longer overall survival rate, regardless of whether the hypopigmentation was the only clinical feature or if there were additional lesional variants of MF [82]. A previous publication concluded that mixed MF has an earlier onset than $\mathrm{HMF}$, and most cases show a phenotype different than $\mathrm{CD} 8^{+}$. Despite these differences, the authors suggested that hypopigmented lesions represent a marker of a favorable prognosis when compared with the conventional erythematous patch/plaque MF [83]. These combined results indicate that the presentation of hypopigmented lesions, solely or concomitantly with other variants of MF or other clinical presentations, represents an active antitumor immune response, and therefore portends a favorable disease prognosis. 
Table 1. Cases of hypopigmented mycosis fungoides with T-cell phenotype other than CD8 ${ }^{+}$. Cases published up to March 2020.

\begin{tabular}{|c|c|c|c|c|c|c|}
\hline Study & Number of Patients & T-Cell Phenotype & Age of Onset (years) & $\begin{array}{c}\text { Fitzpatrick } \\
\text { Phototype/Color of } \\
\text { Skin/ Ethnicity }\end{array}$ & Stage at Diagnosis & Disease Progressec \\
\hline Sigal et al., 1987 [79] & 1 & $\mathrm{CD}^{+}$ & 64 & Caucasian & $\mathrm{NS}^{\mathrm{a}}$ & Yes $^{\text {a }}$ \\
\hline Lambroza et al., 1995 [84] & 1 & $\mathrm{CD}^{+}$ & 25 & Trinidadian & IB & No \\
\hline Moulonguet et al., 1998 [85] & 1 & $\mathrm{CD}^{+}$ & 31 & $\begin{array}{l}\text { Caucasian/Light } \\
\text { skinned }\end{array}$ & IA & No \\
\hline Grunwald and Amichai, 1999 [86] & 1 & $\mathrm{CD}^{+}$ & 12 & Caucasian & NS & No \\
\hline Quaglino et al., 1999 [87] & 1 & $\mathrm{CD}^{+}$ & 16 & White & IA & No \\
\hline Qari et al., 2000 [88] & 3 & $\begin{array}{c}\mathrm{CD} 4^{+}: 2 \text { patients } \\
\mathrm{CD}^{+} / \mathrm{CD}^{+}: 1 \text { patient }\end{array}$ & 31 (mean) & $\begin{array}{l}\text { Hispanic, Portuguese } \\
\text { black, and African- } \\
\text { American }\end{array}$ & NS & NS \\
\hline Stone et al., 2001 [80] & 1 & $\mathrm{CD}^{+}$ & 56 & Black & I & Yes $^{b}$ \\
\hline Ardigo et al., 2003 [16] & 5 & $\begin{array}{c}\mathrm{CD}^{+}: 4 \\
\mathrm{CD} 4^{+} / \mathrm{CD}^{+}: 1 \\
\end{array}$ & 34.4 (mean) & Caucasian & NS & NS \\
\hline Gulekon et al., 2005 [89] & 1 & $\mathrm{CD}^{+}$ & 3 & Turkish & NS & NS \\
\hline Hodak et al., 2005 [90] & 2 & $\mathrm{CD}^{+}$ & 1 (mean) & NS & IB and IA & 1 patient (IIA) \\
\hline Wain et al., 2005 [91] & 2 & $\mathrm{CD}^{2} 6^{+}$ & 21.5 (mean) & Asian and Somalian & IA and IB & No \\
\hline Onsun et al., 2006 [92] & 1 & $\mathrm{CD}^{+}$ & 8 & Type II & IB & No \\
\hline Hodak et al., 2006 [48] & 5 & $\mathrm{CD} 4^{-} / \mathrm{CD}^{-}$ & $\begin{array}{l}17.8 \text { (mean at } \\
\text { diagnosis) }\end{array}$ & NS & $\begin{array}{l}\text { IA: } 1 \text { patient } \\
\text { IB: } 4 \text { patients }\end{array}$ & No \\
\hline Grover et al., 2010 [93] & 1 & $\mathrm{CD}^{+}$ & 2 & Indian & IB & No \\
\hline Koorse et al., 2012 [94] & 4 & $\mathrm{CD}^{+}$ & NS & Indian & NS & NS \\
\hline $\begin{array}{l}\text { Hassab-El-Naby and El-Khalawany, } \\
2013 \text { [95] }\end{array}$ & 9 & $\mathrm{CD}^{+}$ & 37 (mean) & $\begin{array}{l}\text { Type III: } 4 \text { patients } \\
\text { Type IV: } 5 \text { patients }\end{array}$ & $\begin{array}{l}\text { IA: } 7 \text { patients } \\
\text { IB: } 2 \text { patients }\end{array}$ & No \\
\hline Zhang and $\mathrm{Yu}, 2013$ [96] & 1 & $\mathrm{CD} 4^{+} / \mathrm{CD}^{+}$ & 9 & Chinese & NS & NS \\
\hline Alhumidi, 2014 [97] & 4 & $\begin{array}{c}\mathrm{CD} 4^{+}: 2 \text { patients } \\
\mathrm{CD} 4^{+} / \mathrm{CD} 8^{+}: 2 \text { patients }\end{array}$ & 23 (mean) & $\begin{array}{l}\text { Saudi Arabian } \\
\text { Type III }\end{array}$ & NS & $\mathrm{No}^{c}$ \\
\hline Boulos et al., 2014 [98] & 7 & $\mathrm{CD}^{+}$ & 8.8 (mean) & & $\begin{array}{l}\text { IA: } 3 \text { patients } \\
\text { IB: } 4 \text { patients }\end{array}$ & 1 patient $(\mathrm{IB})$ \\
\hline Furlan et al., 2014 [12] & 4 & $\mathrm{CD}^{+}$ & 31 (mean) & $\begin{array}{l}\text { Caucasian mixed race } \\
\text { and black }\end{array}$ & $\begin{array}{l}\text { IA: } 1 \text { patient } \\
\text { IB: } 2 \text { patients } \\
\text { IIA: } 1 \text { patient }\end{array}$ & NS \\
\hline
\end{tabular}


Table 1. Cont

\begin{tabular}{|c|c|c|c|c|c|c|c|c|}
\hline Study & Number of Patients & \multicolumn{2}{|c|}{ T-Cell Phenotype } & \multicolumn{2}{|c|}{ Age of Onset (years) } & $\begin{array}{c}\text { Fitzpatrick } \\
\text { Phototype/Color of } \\
\text { Skin/ Ethnicity }\end{array}$ & Stage at Diagnosis & Disease Progressed \\
\hline Abdel-Halin et al., 2015 [99] & 8 & \multicolumn{2}{|c|}{$\begin{array}{c}\mathrm{CD} 4^{+}: 3 \text { patients } \\
\mathrm{CD} 4^{+} / \mathrm{CD}^{+}: 5 \text { patients }\end{array}$} & \multicolumn{2}{|l|}{ NS } & Egyptian & NS & NS \\
\hline Mateeva and Kadurina, 2015 [100] & 1 & \multicolumn{2}{|l|}{$\mathrm{CD}^{+}$} & \multicolumn{2}{|l|}{22} & $\begin{array}{c}\text { Caucasian/Bulgarian } \\
\text { descent } \\
\text { Type III }\end{array}$ & NS & No \\
\hline Rowe et al., 2016 [11] & 1 & \multicolumn{2}{|l|}{$\mathrm{CD}^{+}$} & \multicolumn{2}{|l|}{71} & Dark skin & NS $^{d}$ & NS \\
\hline Cervini et al., 2017 [76] & 8 & \multicolumn{2}{|c|}{$\begin{array}{c}\mathrm{CD} 4^{+}: 2 \text { patients } \\
\mathrm{CD} 4^{+} / \mathrm{CD}^{+}: 6 \text { patients }\end{array}$} & \multicolumn{2}{|c|}{$\begin{array}{c}11.8 \text { (mean at } \\
\text { diagnosis) }\end{array}$} & Argentinian & $\begin{array}{l}\text { IA: } 1 \text { patient } \\
\text { IB: } 7 \text { patients }\end{array}$ & Yes $^{\mathrm{e}}$ \\
\hline Rodney et al., 2017 [9] & 5 & \multicolumn{2}{|c|}{$\begin{array}{c}\mathrm{CD} 4^{+}: 3 \text { patients } \\
\mathrm{CD} 4^{+} / \mathrm{CD}^{+}: 2 \text { patients }\end{array}$} & \multicolumn{2}{|c|}{36 (mean) } & $\begin{array}{l}\text { African-American } \\
\text { and African }\end{array}$ & $\begin{array}{l}\text { IA: } 1 \text { patient } \\
\text { IB: } 4 \text { patients }\end{array}$ & No \\
\hline Joseph et al., 2018 [101] & 1 & \multicolumn{2}{|l|}{$\mathrm{CD}^{+}$} & \multicolumn{2}{|l|}{50} & NS & IA & No \\
\hline Vilas Boas et al., 2018 [102] & 1 & \multicolumn{2}{|l|}{$\mathrm{CD}^{+}$} & \multicolumn{2}{|l|}{5} & Hispanic & NS & NS \\
\hline Landgrave-Gomez et al., 2019 [103] & 6 & \multicolumn{2}{|c|}{$\begin{array}{c}\mathrm{CD} 4^{+}: 2 \text { patients } \\
\mathrm{CD} 4^{+} / \mathrm{CD}^{+}: 4 \text { patients } \\
\end{array}$} & \multicolumn{2}{|c|}{ NS } & NS & NS & NS \\
\hline \multicolumn{9}{|c|}{$\begin{array}{l}\text { NS, not specified. a Staging not specified. However, since the initial diagnosis, the patient presented with lymph node involvement and after } 2 \text { years, the patient died of septicemia and } \\
\text { bone marrow aplasia. }{ }^{b} \text { Disease progression to another stage not specified. After } 2 \text { years, the patient presented with erythematous plaques, nodules, and tumors and the authors suspected } \\
\text { lymphomatous spread from MF. The patient died of acute respiratory distress syndrome. }{ }^{c} \text { The authors mentioned an indolent course for the cohort of patients. }{ }^{d} \text { Staging was not stated. } \\
\text { However, the authors reported lymphadenopathy and tumor stage MF. }{ }^{e} \text { The new stage was not stated. However, the authors mentioned that two patients progressed to a higher body } \\
\text { surface area involvement, but no systemic disease. }\end{array}$} \\
\hline Study & Number of Patients & Age of Onset (years) & $\begin{array}{r}\text { F } \\
\text { Photo } \\
\text { Ski }\end{array}$ & $\begin{array}{l}\text { tzpatrick } \\
\text { type/Color of } \\
\text { 2/ Ethnicity }\end{array}$ & Other & $\begin{array}{l}\text { Variants of MF as } \\
\text { Published }\end{array}$ & Stage at Diagnosis & $\begin{array}{c}\text { Disease } \\
\text { Progressed }\end{array}$ \\
\hline Sigal et al., 1987 [79] & 1 & 64 & & White & Erytl & nematous papules & $\mathrm{NS}^{\mathrm{a}}$ & Yes $^{\text {a }}$ \\
\hline $\begin{array}{c}\text { el-Hoshy and Hashimoto, } \\
1995 \text { [104] }\end{array}$ & 1 & 15 & & Black & Eryth & nematous nodules & NS & No \\
\hline Lambroza et al., 1995 [84] & 1 & 21 & Jamai & an-American & & perpigmented & IB & No \\
\hline Qari et al., 2000 [88] & 3 & 25.3 (mean) & $\begin{array}{c}\text { Hisp } \\
\text { Port }\end{array}$ & $\begin{array}{l}\text { nic/dark and } \\
\text { guese/black }\end{array}$ & $\begin{array}{l}\text { Red pa } \\
\text { eryth }\end{array}$ & $\begin{array}{l}\text { pules, pink patches, } \\
\text { ematous, and scaly } \\
\text { plaques }\end{array}$ & NS & No \\
\hline
\end{tabular}


Table 2. Cont.

\begin{tabular}{|c|c|c|c|c|c|c|}
\hline Study & Number of Patients & Age of Onset (years) & $\begin{array}{c}\text { Fitzpatrick } \\
\text { Phototype/Color of } \\
\text { Skin/ Ethnicity }\end{array}$ & $\begin{array}{c}\text { Other Variants of MF as } \\
\text { Published }\end{array}$ & Stage at Diagnosis & $\begin{array}{l}\text { Disease } \\
\text { Progressed }\end{array}$ \\
\hline Stone et al., 2000 [80] & 1 & 56 & Type V & $\begin{array}{l}\text { Hyperpigmented macules } \\
\text { later evolved to } \\
\text { erythematous lesions }\end{array}$ & I & Yes $^{b}$ \\
\hline Ardigo et al., 2003 [16] & 6 & 30.1 (mean) & Caucasian & Erythematous lesions & NS & 2 patients ${ }^{c}$ \\
\hline Ben-Amitai et al., 2003 [105] & 5 & 4.6 (mean) & Light and pigmented & Classic erythematous lesions & $\begin{array}{l}\text { IA: } 2 \text { patients } \\
\text { IB: } 3 \text { patients }\end{array}$ & No \\
\hline Wain et al., 2003 [75] & 2 & 10.5 (mean) & NS & Poikiloderma and pilotropic & IB & No \\
\hline Hodak et al., 2005 [90] & 2 & 1 (mean) & NS & Psoriasiform & IB and IA & 1 patient (IIA) \\
\hline Wain et al., 2005 [91] & 2 & 21.5 (mean) & Asian and Somalian & $\begin{array}{l}\text { Poikiloderma and } \\
\text { hyperpigmented }\end{array}$ & IA and IB & No \\
\hline Hodak et al., 2006 [48] & 1 & 12 (at diagnosis) & NS & Classic & IB & No \\
\hline Hsiao et al., 2006 [106] & 1 & 12 & NS & Hyperpigmented & IA & No \\
\hline Onsun et al., 2006 [92] & 1 & 5 (mean) & $\begin{array}{l}\text { Type II: } 1 \text { patient } \\
\text { Type III: } 1 \text { patient }\end{array}$ & Erythematous & IB & No \\
\hline Ozcan et al., 2008 [107] & 1 & 30 & Turkish & Erythematous & NS & NS \\
\hline Nanda et al., 2010 [109] & 3 & 7.5 (mean) & Bedouin and Kuwaiti & $\begin{array}{l}\text { Pityriasis lichenoides } \\
\text { chronica-like and } \\
\text { folliculotropic }\end{array}$ & IA, IB, and IIA & NS \\
\hline Khopkar et al., 2011 [110] & 5 & 19 (mean) & $\begin{array}{l}\text { Asian with dark skin } \\
\text { type }\end{array}$ & $\begin{array}{l}\text { Poikiloderma and } \\
\text { erythematous }\end{array}$ & NS ${ }^{d}$ & $\mathrm{NS}^{\mathrm{d}}$ \\
\hline Yazganoglu et al., 2013 [74] & 8 & 6.1 (mean) & NS & Erythematous and purpuric & $\begin{array}{l}\text { IA: } 5 \text { patients } \\
\text { IB: } 3 \text { patients }\end{array}$ & No \\
\hline Rizzo et al., 2012 [111] & 1 & 15 (at diagnosis) & NS & Erythematous & IB & NS \\
\hline $\begin{array}{l}\text { Uhlenhake and Mehregan, } \\
2012 \text { [112] }\end{array}$ & 1 & 49 & African-American & $\begin{array}{c}\text { Hypopigmented macules } \\
\text { with } \\
\text { hyperpigmented/erythematous } \\
\text { centers }\end{array}$ & NS & NS \\
\hline $\begin{array}{l}\text { Wongpraparut and Setabutra, } \\
2012[113]\end{array}$ & 1 & 36 & Type IV & Erythematous & IA & No \\
\hline
\end{tabular}


Table 2. Cont.

\begin{tabular}{|c|c|c|c|c|c|c|}
\hline Study & Number of Patients & Age of Onset (years) & $\begin{array}{c}\text { Fitzpatrick } \\
\text { Phototype/Color of } \\
\text { Skin/ Ethnicity }\end{array}$ & $\begin{array}{l}\text { Other Variants of MF as } \\
\text { Published }\end{array}$ & Stage at Diagnosis & $\begin{array}{c}\text { Disease } \\
\text { Progressed }\end{array}$ \\
\hline Ahumidi, 2014 [97] & 1 & 5 & Type III e & Pink papules & NS & NS \\
\hline Furlan et al., 2014 [83] & 14 & 29.5 (median) & $\begin{array}{c}\text { Mixed race, } \\
\text { Caucasian, Black, and } \\
\text { Asian/Brazilian }\end{array}$ & $\begin{array}{l}\text { Erythematous, poikiloderma, } \\
\text { hyperpigmented, purpuric, } \\
\text { and hyperkeratotic }\end{array}$ & $\begin{array}{l}\text { IA: } 7 \text { patients } \\
\text { IB: } 6 \text { patients } \\
\text { IIA: } 1 \text { patient }\end{array}$ & NS \\
\hline Gameiro et al., 2014 [114] & 1 & 5 & Type III & Erythematous papules & IB & No \\
\hline Heng et al., 2014 [115] & 11 & NS & $\begin{array}{l}\text { Chinese, Malay, } \\
\text { Indian, and others }\end{array}$ & $\begin{array}{l}\text { Red, scaly papules and } \\
\text { plaques }\end{array}$ & NS & NS \\
\hline $\begin{array}{c}\text { Fatemi Naeini et al., } \\
2015 \text { [116] }\end{array}$ & 2 & NS & Iranian & NS & NS & NS \\
\hline Naeini et al., 2015 [117] & 1 & 26 & Iranian & Erythematous & IB & NS \\
\hline Ichimura et al., 2016 [118] & 1 & 20 & Japanese & Scaly erythema & IB & No \\
\hline Cervini et al., 2017 [76] & 2 & 11 (mean at diagnosis) & Argentinian & Classic MF & $\mathrm{IVA}^{\mathrm{f}}$ and IB & No \\
\hline Pradhan et al., 2017 [81] & 1 & 2 & Iranian & Large cell transformation & IB & No \\
\hline $\begin{array}{c}\text { Landgrave-Gomez et al., } \\
2019 \text { [103] }\end{array}$ & NS & NS & Hispanic & $\begin{array}{l}\text { Hyperpigmentation and } \\
\text { erythema }\end{array}$ & NS & NS \\
\hline $\begin{array}{c}\text { Valencia Ocampo et al., } \\
2019 \text { [119] }\end{array}$ & 5 & 7.8 (mean) & $\begin{array}{l}\text { Type II: } 1 \text { patient } \\
\text { Type III: } 1 \text { patient } \\
\text { Type IV: } 2 \text { patients } \\
\text { Type V: } 1 \text { patient }\end{array}$ & Erythematous & $\begin{array}{l}\text { IA: } 1 \text { patient } \\
\text { IB: } 4 \text { patients }\end{array}$ & No \\
\hline Geller et al., 2019 [82] & 34 & NS & African-American & $\begin{array}{l}\text { Erythematous and } \\
\text { hyperpigmented }\end{array}$ & NS & No \\
\hline Kalay et al., 2020 [120] & 4 & $\begin{array}{l}30.5 \text { (mean at } \\
\text { diagnosis) }\end{array}$ & Turkish & $\begin{array}{l}\text { Follicular hyperkeratosis, } \\
\text { erythematous, and } \\
\text { hyperpigmented }\end{array}$ & IA & No \\
\hline \multicolumn{7}{|c|}{$\begin{array}{l}\text { NS, not specified. a Staging not specified. However, since the initial diagnosis, the patient presented with lymph node involvement and after } 2 \text { years, the patient died of septicemia and } \\
\text { bone marrow aplasia. b Disease progression to another stage not specified. After } 2 \text { years, the patient presented with erythematous plaques, nodules, and tumors and the authors suspected } \\
\text { lymphomatous spread from MF. The patient died of acute respiratory distress syndrome. }{ }^{c} \text { Progressive disease, but no new stage mentioned. }{ }^{d} \text { The authors mentioned that patients did } \\
\text { not show lymph enlargement or visceral involvement and remained with same clinical characteristics. }{ }^{\mathrm{e}} \text { The authors did not report phototype for each patient. However, the authors } \\
\text { mentioned that Saudi Arabian individuals are mostly skin phototype III-IV. }{ }^{\mathrm{f}} \text { Lymph node involvement documented. However, this patient had a follow up of } 7.5 \text { years and remained } \\
\text { disease-free for } 4 \text { years without progression. }\end{array}$} \\
\hline
\end{tabular}




\section{Conclusions}

Two of the differentiating characteristics of HMF, its earlier onset and favorable prognosis, can be explained through the involvement of an active antitumor immune response. Specifically, the immunopathogenesis of MF implies an activation of the cytotoxic immune response, the adaptive antitumor immunity. Importantly, the three phases of cancer immunoediting correlate with the different cellular and cytokine profiles of MF. We suggest that HMF remains in the equilibrium phase, which is characterized by a balance between surviving and dying tumor cells. Evidence of HMF maintenance of equilibrium phase includes TILs that are positive for cytotoxic molecules such as TIA1, granzyme $\mathrm{B}$, and granulysin as well as high levels of TNF- $\alpha$ cytokine in lesional skin, indicating a robust Th1 immune response. Additionally, lower Treg cell levels found in HMF patient skin lesions further supports the notion of active immunosurveillance.

Furthermore, we propose that hypopigmentation in the case of HMF constitutes a surrogate clinical marker for the active antitumor immune response, and therefore a favorable prognostic indicator in these patients. Specifically, tumor-targeting immune cells are thought to cause the observed inflammatory hypopigmentation. Decreased levels of bFGF, CD117, tyrosinase, MART-1/melan-A, gp100, and MiTF indicate/lead to disrupted melanocyte function: altered melanogenesis and induction of melanocyte apoptosis. Moreover, a decreased level of bFGF is related to an increased level of the Th1 cytokine TNF- $\alpha$ in HMF.

Clinically, this active immune response correlates positively with the earlier age of disease onset in HMF patients. Even though MF is not common among young individuals, HMF is overrepresented in this group, with most cases diagnosed in early stages and without progression. We speculate that there are likely many more Caucasian patients, who develop mild HMF disease and recover from it with favorable prognosis. Since the lesions are less apparent and could be confused for mild eczema (pityriasis alba), many are likely never brought to the attention of a dermatologist or biopsied to enable the diagnosis of HMF in this Fitzpatrick type I-II skin phototype patient population.

The research presented in this review has limitations. The incidence of MF is relatively low and its exact incidence is unknown. Therefore, there is limited literature investigating this variant that may be underestimated due to misdiagnosis and clinical masquerading. The majority of publications perform immunohistochemistry, and while this approach is valid for patient samples, recent studies use a more comprehensive approach with several techniques such as genome or RNA sequencing. Finally, there is a lack of continuity regarding the research results in HMF, where biomarkers remain poorly defined/validated. Improved understanding of the molecular features that account for HMF behavior may allow dermatologists and cutaneous oncologists to accurately diagnose and prognosticate patients suffering from this disease. Furthermore, the knowledge generated by studying HMF can be applied in other MF variants, other lymphomas, or even different types of cancer. HMF is an intriguing model for the development of new targeted therapies due to the ease of accessibility to skin lesions and its overall excellent prognosis.

Supplementary Materials: The following are available online at http://www.mdpi.com/2072-6694/12/8/2007/s1, Table S1: Hypopigmented mycosis fungoides with Fitzpatrick phototype classification. Cases published up to March 2020. Table S2: Hypopigmented mycosis fungoides without Fitzpatrick phototype classification. Cases published up to March 2020.

Author Contributions: Writing —original draft preparation, A.M.V.; writing—review and editing, A.M.V., J.G., A.B., D.S., F.L., N.Ø., Y.V.C.-J., A.H.S., and I.V.L. All authors have read and agreed to the published version of the manuscript.

Funding: This work was supported by the Canadian Dermatology Foundation research grants to Sasseville and Litvinov and Canadian Institutes of Health Research grants (RN404871-428712; RN402034-427902) by the Fonds de la recherche du Québec-Santé (FRQS) (\#34753 and \#36769) to Litvinov. Martínez Villarreal received fellowship support from CONACYT (Government of Mexico) and the Cole Foundation, while Gantchev (M.Sc.) received a doctorate scholarship from FRQS and Ph.D. fellowship from the Cole Foundation.

Conflicts of Interest: The authors declare no conflict of interest. 


\section{References}

1. Pulitzer, M. Cutaneous T-cell Lymphoma. Clin. Lab. Med. 2017, 37, 527-546. [CrossRef] [PubMed]

2. Bagherani, N.; Smoller, B.R. An overview of cutaneous T cell lymphomas. F1000Res. 2016, 5. [CrossRef] [PubMed]

3. Ghazawi, F.M.; Alghazawi, N.; Le, M.; Netchiporouk, E.; Glassman, S.J.; Sasseville, D.; Litvinov, I.V. Environmental and Other Extrinsic Risk Factors Contributing to the Pathogenesis of Cutaneous T Cell Lymphoma (CTCL). Front. Oncol. 2019, 9, 300. [CrossRef] [PubMed]

4. Querfeld, C.; Zain, J.; Rosen, S.T. Primary Cutaneous T-Cell Lymphomas: Mycosis Fungoides and Sezary Syndrome. Cancer Treat. Res. 2019, 176, 225-248. [CrossRef] [PubMed]

5. Litvinov, I.V.; Tetzlaff, M.T.; Rahme, E.; Habel, Y.; Risser, D.R.; Gangar, P.; Jennings, M.A.; Pehr, K.; Prieto, V.G.; Sasseville, D.; et al. Identification of geographic clustering and regions spared by cutaneous T-cell lymphoma in Texas using 2 distinct cancer registries. Cancer 2015, 121, 1993-2003. [CrossRef] [PubMed]

6. Howard, M.S.; Smoller, B.R. Mycosis fungoides: Classic disease and variant presentations. Semin. Cutan. Med. Surg. 2000, 19, 91-99. [CrossRef]

7. Jawed, S.I.; Myskowski, P.L.; Horwitz, S.; Moskowitz, A.; Querfeld, C. Primary cutaneous T-cell lymphoma (mycosis fungoides and Sezary syndrome): Part I. Diagnosis: Clinical and histopathologic features and new molecular and biologic markers. J. Am. Acad. Derm. 2014, 70, 205.e1-205.e16. [CrossRef]

8. Furlan, F.C.; Sanches, J.A. Hypopigmented mycosis fungoides: A review of its clinical features and pathophysiology. Bras. Derm. 2013, 88, 954-960. [CrossRef]

9. Rodney, I.J.; Kindred, C.; Angra, K.; Qutub, O.N.; Villanueva, A.R.; Halder, R.M. Hypopigmented mycosis fungoides: A retrospective clinicohistopathologic study. J. Eur. Acad. Derm. Venereol. 2017, 31, 808-814. [CrossRef]

10. Castano, E.; Glick, S.; Wolgast, L.; Naeem, R.; Sunkara, J.; Elston, D.; Jacobson, M. Hypopigmented mycosis fungoides in childhood and adolescence: A long-term retrospective study. J. Cutan. Pathol. 2013, 40, 924-934. [CrossRef]

11. Rowe, B.; Shevchenko, A.; Yosipovitch, G. Leser-Trelat Sign in Tumor-Stage Mycosis Fungoides. Dermatol. Online J. 2016, 22.

12. Furlan, F.C.; de Paula Pereira, B.A.; da Silva, L.F.; Sanches, J.A. Loss of melanocytes in hypopigmented mycosis fungoides: A study of 18 patients. J. Cutan. Pathol. 2014, 41, 101-107. [CrossRef] [PubMed]

13. El-Darouti, M.A.; Marzouk, S.A.; Azzam, O.; Fawzi, M.M.; Abdel-Halim, M.R.; Zayed, A.A.; Leheta, T.M. Vitiligo vs. hypopigmented mycosis fungoides (histopathological and immunohistochemical study, univariate analysis). Eur. J. Derm. 2006, 16, 17-22.

14. Hodak, E.; Phenig, E.; Amichai, B.; Feinmesser, M.; Kuten, A.; Maron, L.; Sahar, D.; Bergman, R.; David, M. Unilesional mycosis fungoides: A study of seven cases. Dermatology 2000, 201, 300-306. [CrossRef]

15. Amorim, G.M.; Niemeyer-Corbellini, J.P.; Quintella, D.C.; Cuzzi, T.; Ramos, E.S.M. Hypopigmented mycosis fungoides: A 20-case retrospective series. Int. J. Derm. 2018, 57, 306-312. [CrossRef]

16. Ardigo, M.; Borroni, G.; Muscardin, L.; Kerl, H.; Cerroni, L. Hypopigmented mycosis fungoides in Caucasian patients: A clinicopathologic study of 7 cases. J. Am. Acad. Derm. 2003, 49, 264-270. [CrossRef]

17. Whittam, L.R.; Calonje, E.; Orchard, G.; Fraser-Andrews, E.A.; Woolford, A.; Russell-Jones, R. CD8-positive juvenile onset mycosis fungoides: An immunohistochemical and genotypic analysis of six cases. Br. J. Derm. 2000, 143, 1199-1204. [CrossRef]

18. El-Shabrawi-Caelen, L.; Cerroni, L.; Medeiros, L.J.; McCalmont, T.H. Hypopigmented mycosis fungoides: Frequent expression of a CD8+ T-cell phenotype. Am. J. Surg. Pathol. 2002, 26, 450-457. [CrossRef]

19. Ngo, J.T.; Trotter, M.J.; Haber, R.M. Juvenile-onset hypopigmented mycosis fungoides mimicking vitiligo. J. Cutan. Med. Surg. 2009, 13, 230-233. [CrossRef]

20. Litvinov, I.V.; Shtreis, A.; Kobayashi, K.; Glassman, S.; Tsang, M.; Woetmann, A.; Sasseville, D.; Odum, N.; Duvic, M. Investigating potential exogenous tumor initiating and promoting factors for Cutaneous T-Cell Lymphomas (CTCL), a rare skin malignancy. Oncoimmunology 2016, 5, e1175799. [CrossRef]

21. Gallardo, F.; Sandoval, J.; Diaz-Lagares, A.; Garcia, R.; D’Altri, T.; Gonzalez, J.; Alegre, V.; Servitje, O.; Crujeiras, A.B.; Stefansson, O.A.; et al. Notch1 Pathway Activation Results from the Epigenetic Abrogation of Notch-Related MicroRNAs in Mycosis Fungoides. J. Invest. Derm. 2015, 135, 3144-3152. [CrossRef] [PubMed] 
22. Lundin Brockdorff, J.; Woetmann, A.; Mustelin, T.; Kaltoft, K.; Zhang, Q.; Wasik, M.A.; Ropke, C.; Odum, N. SHP2 regulates IL-2 induced MAPK activation, but not Stat 3 or Stat 5 tyrosine phosphorylation, in cutaneous T cell lymphoma cells. Cytokine 2002, 20, 141-147. [CrossRef] [PubMed]

23. Ghazawi, F.M.; Netchiporouk, E.; Rahme, E.; Tsang, M.; Moreau, L.; Glassman, S.; Provost, N.; Gilbert, M.; Jean, S.E.; Pehr, K.; et al. Comprehensive analysis of cutaneous T-cell lymphoma (CTCL) incidence and mortality in Canada reveals changing trends and geographic clustering for this malignancy. Cancer 2017, 123, 3550-3567. [CrossRef] [PubMed]

24. Ghazawi, F.M.; Netchiporouk, E.; Rahme, E.; Tsang, M.; Moreau, L.; Glassman, S.; Provost, N.; Gilbert, M.; Jean, S.E.; Roshdy, O.; et al. Distribution and Clustering of Cutaneous T-Cell Lymphoma (CTCL) Cases in Canada During 1992 to 2010. J. Cutan. Med. Surg. 2018, 22, 154-165. [CrossRef] [PubMed]

25. Kim, E.J.; Hess, S.; Richardson, S.K.; Newton, S.; Showe, L.C.; Benoit, B.M.; Ubriani, R.; Vittorio, C.C.; Junkins-Hopkins, J.M.; Wysocka, M.; et al. Immunopathogenesis and therapy of cutaneous T cell lymphoma. J. Clin. Investig. 2005, 115, 798-812. [CrossRef]

26. Kupper, T.S.; Fuhlbrigge, R.C. Immune surveillance in the skin: Mechanisms and clinical consequences. Nat. Rev. Immunol. 2004, 4, 211-222. [CrossRef]

27. Girardi, M.; Heald, P.W.; Wilson, L.D. The pathogenesis of mycosis fungoides. N. Engl. J. Med. 2004, 350, 1978-1988. [CrossRef] [PubMed]

28. Krejsgaard, T.; Lindahl, L.M.; Mongan, N.P.; Wasik, M.A.; Litvinov, I.V.; Iversen, L.; Langhoff, E.; Woetmann, A.; Odum, N. Malignant inflammation in cutaneous T-cell lymphoma-a hostile takeover. Semin. Immunopathol. 2017, 39, 269-282. [CrossRef]

29. Krejsgaard, T.; Willerslev-Olsen, A.; Lindahl, L.M.; Bonefeld, C.M.; Koralov, S.B.; Geisler, C.; Wasik, M.A.; Gniadecki, R.; Kilian, M.; Iversen, L.; et al. Staphylococcal enterotoxins stimulate lymphoma-associated immune dysregulation. Blood 2014, 124, 761-770. [CrossRef] [PubMed]

30. Sommer, V.H.; Clemmensen, O.J.; Nielsen, O.; Wasik, M.; Lovato, P.; Brender, C.; Eriksen, K.W.; Woetmann, A.; Kaestel, C.G.; Nissen, M.H.; et al. In vivo activation of STAT3 in cutaneous T-cell lymphoma. Evidence for an antiapoptotic function of STAT3. Leukemia 2004, 18, 1288-1295. [CrossRef]

31. Litvinov, I.V.; Cordeiro, B.; Fredholm, S.; Odum, N.; Zargham, H.; Huang, Y.; Zhou, Y.; Pehr, K.; Kupper, T.S.; Woetmann, A.; et al. Analysis of STAT4 expression in cutaneous T-cell lymphoma (CTCL) patients and patient-derived cell lines. Cell Cycle 2014, 13, 2975-2982. [CrossRef] [PubMed]

32. Netchiporouk, E.; Litvinov, I.V.; Moreau, L.; Gilbert, M.; Sasseville, D.; Duvic, M. Deregulation in STAT signaling is important for cutaneous T-cell lymphoma (CTCL) pathogenesis and cancer progression. Cell Cycle 2014, 13, 3331-3335. [CrossRef] [PubMed]

33. Sibbesen, N.A.; Kopp, K.L.; Litvinov, I.V.; Jonson, L.; Willerslev-Olsen, A.; Fredholm, S.; Petersen, D.L.; Nastasi, C.; Krejsgaard, T.; Lindahl, L.M.; et al. Jak3, STAT3, and STAT5 inhibit expression of miR-22, a novel tumor suppressor microRNA, in cutaneous T-Cell lymphoma. Oncotarget 2015, 6, 20555-20569. [CrossRef]

34. Huang, Y.; Litvinov, I.V.; Wang, Y.; Su, M.W.; Tu, P.; Jiang, X.; Kupper, T.S.; Dutz, J.P.; Sasseville, D.; Zhou, Y. Thymocyte selection-associated high mobility group box gene (TOX) is aberrantly over-expressed in mycosis fungoides and correlates with poor prognosis. Oncotarget 2014, 5, 4418-4425. [CrossRef] [PubMed]

35. Dulmage, B.O.; Akilov, O.; Vu, J.R.; Falo, L.D.; Geskin, L.J. Dysregulation of the TOX-RUNX3 pathway in cutaneous T-cell lymphoma. Oncotarget 2019, 10, 3104-3113. [CrossRef] [PubMed]

36. Willerslev-Olsen, A.; Litvinov, I.V.; Fredholm, S.M.; Petersen, D.L.; Sibbesen, N.A.; Gniadecki, R.; Zhang, Q.; Bonefeld, C.M.; Wasik, M.A.; Geisler, C.; et al. IL-15 and IL-17F are differentially regulated and expressed in mycosis fungoides (MF). Cell Cycle 2014, 13, 1306-1312. [CrossRef]

37. Lindahl, L.M.; Fredholm, S.; Joseph, C.; Nielsen, B.S.; Jonson, L.; Willerslev-Olsen, A.; Gluud, M.; Blumel, E.; Petersen, D.L.; Sibbesen, N.; et al. STAT5 induces miR-21 expression in cutaneous T cell lymphoma. Oncotarget 2016, 7, 45730-45744. [CrossRef]

38. Lefrancois, P.; Tetzlaff, M.T.; Moreau, L.; Watters, A.K.; Netchiporouk, E.; Provost, N.; Gilbert, M.; Ni, X.; Sasseville, D.; Duvic, M.; et al. TruSeq-Based Gene Expression Analysis of Formalin-Fixed Paraffin-Embedded (FFPE) Cutaneous T-Cell Lymphoma Samples: Subgroup Analysis Results and Elucidation of Biases from FFPE Sample Processing on the TruSeq Platform. Front. Med. (Lausanne) 2017, 4, 153. [CrossRef]

39. Krejsgaard, T.; Litvinov, I.V.; Wang, Y.; Xia, L.; Willerslev-Olsen, A.; Koralov, S.B.; Kopp, K.L.; Bonefeld, C.M.; Wasik, M.A.; Geisler, C.; et al. Elucidating the role of interleukin-17F in cutaneous T-cell lymphoma. Blood 2013, 122, 943-950. [CrossRef] 
40. Le, M.; Ghazawi, F.M.; Netchiporouk, E.; Litvinov, I.V. The Novel Role of Antibiotic Treatment in the Management of Cutaneous T-Cell Lymphoma (CTCL) Patients. J. Cutan. Med. Surg. 2020. [CrossRef]

41. Shalabi, D.; Bistline, A.; Alpdogan, O.; Kartan, S.; Mishra, A.; Porcu, P.; Nikbakht, N. Immune evasion and current immunotherapy strategies in mycosis fungoides (MF) and Sezary syndrome (SS). Chin. Clin. Oncol 2019, 8, 11. [CrossRef]

42. Wong, H.K.; Mishra, A.; Hake, T.; Porcu, P. Evolving insights in the pathogenesis and therapy of cutaneous T-cell lymphoma (mycosis fungoides and Sezary syndrome). Br. J. Haematol. 2011, 155, 150-166. [CrossRef] [PubMed]

43. Dunn, G.P.; Old, L.J.; Schreiber, R.D. The immunobiology of cancer immunosurveillance and immunoediting. Immunity 2004, 21, 137-148. [CrossRef] [PubMed]

44. Litvinov, I.V.; Netchiporouk, E.; Cordeiro, B.; Dore, M.A.; Moreau, L.; Pehr, K.; Gilbert, M.; Zhou, Y.; Sasseville, D.; Kupper, T.S. The Use of Transcriptional Profiling to Improve Personalized Diagnosis and Management of Cutaneous T-cell Lymphoma (CTCL). Clin. Cancer Res. 2015, 21, 2820-2829. [CrossRef] [PubMed]

45. Litvinov, I.V.; Jones, D.A.; Sasseville, D.; Kupper, T.S. Transcriptional profiles predict disease outcome in patients with cutaneous T-cell lymphoma. Clin. Cancer Res. 2010, 16, 2106-2114. [CrossRef]

46. Hoppe, R.T.; Medeiros, L.J.; Warnke, R.A.; Wood, G.S. CD8-positive tumor-infiltrating lymphocytes influence the long-term survival of patients with mycosis fungoides. J. Am. Acad. Derm. 1995, 32, 448-453. [CrossRef]

47. Felgar, R.E.; Macon, W.R.; Kinney, M.C.; Roberts, S.; Pasha, T.; Salhany, K.E. TIA-1 expression in lymphoid neoplasms. Identification of subsets with cytotoxic T lymphocyte or natural killer cell differentiation. Am. J. Pathol. 1997, 150, 1893-1900.

48. Hodak, E.; David, M.; Maron, L.; Aviram, A.; Kaganovsky, E.; Feinmesser, M. CD4/CD8 double-negative epidermotropic cutaneous T-cell lymphoma: An immunohistochemical variant of mycosis fungoides. J. Am. Acad. Derm. 2006, 55, 276-284. [CrossRef]

49. Ito, A.; Sugita, K.; Ikeda, A.; Yamamoto, O. CD4/CD8 Double-negative Mycosis Fungoides: A Case Report and Literature Review. Yonago Acta Med. 2019, 62, 153-158. [CrossRef]

50. Nasu-Tababuchi, M.; Fujimura, T.; Kakizaki, A.; Shido, K.; Hatchome, N.; Kusakari, Y.; Aiba, S. Hypopigmented mycosis fungoides: An immunological investigation of tumor-infiltrating $\mathrm{T}$ cells. Dermatol. Sin. 2016, 34, 96-98. [CrossRef]

51. Bots, M.; Medema, J.P. Granzymes at a glance. J. Cell Sci. 2006, 119, 5011-5014. [CrossRef] [PubMed]

52. Youssef, R.; Mahgoub, D.; Zeid, O.A.; Abdel-Halim, D.M.; El-Hawary, M.; Hussein, M.F.; Morcos, M.A.; Aboelfadl, D.M.; Abdelkader, H.A.; Abdel-Galeil, Y.; et al. Hypopigmented Interface T-Cell Dyscrasia and Hypopigmented Mycosis Fungoides: A Comparative Study. Am. J. Derm. 2018, 40, 727-735. [CrossRef] [PubMed]

53. Krensky, A.M.; Clayberger, C. Biology and clinical relevance of granulysin. Tissue Antigens 2009, 73, $193-198$. [CrossRef] [PubMed]

54. Seif El Nasr, H.; Shaker, O.G.; Fawzi, M.M.; El-Hanafi, G. Basic fibroblast growth factor and tumour necrosis factor alpha in vitiligo and other hypopigmented disorders: Suggestive possible therapeutic targets. J. Eur. Acad. Derm. Venereol. 2013, 27, 103-108. [CrossRef]

55. Chuang, G.S.; Wasserman, D.I.; Byers, H.R.; Demierre, M.F. Hypopigmented T-cell dyscrasia evolving to hypopigmented mycosis fungoides during etanercept therapy. J. Am. Acad. Derm. 2008, 59, S121-S122. [CrossRef]

56. Tsang, M.; Gantchev, J.; Netchiporouk, E.; Moreau, L.; Ghazawi, F.M.; Glassman, S.; Sasseville, D.; Litvinov, I.V. A study of meiomitosis and novel pathways of genomic instability in cutaneous T-cell lymphomas (CTCL). Oncotarget 2018, 9, 37647-37661. [CrossRef]

57. Litvinov, I.V.; Tetzlaff, M.T.; Thibault, P.; Gangar, P.; Moreau, L.; Watters, A.K.; Netchiporouk, E.; Pehr, K.; Prieto, V.G.; Rahme, E.; et al. Gene expression analysis in Cutaneous T-Cell Lymphomas (CTCL) highlights disease heterogeneity and potential diagnostic and prognostic indicators. Oncoimmunology 2017, 6, e1306618. [CrossRef]

58. Lefrancois, P.; Xie, P.; Wang, L.; Tetzlaff, M.T.; Moreau, L.; Watters, A.K.; Netchiporouk, E.; Provost, N.; Gilbert, M.; Ni, X.; et al. Gene expression profiling and immune cell-type deconvolution highlight robust disease progression and survival markers in multiple cohorts of CTCL patients. Oncoimmunology 2018, 7, e1467856. [CrossRef] 
59. Gantchev, J.; Martinez Villarreal, A.; Xie, P.; Lefrancois, P.; Gunn, S.; Netchiporouk, E.; Sasseville, D.; Litvinov, I.V. The Ectopic Expression of Meiosis Regulatory Genes in Cutaneous T-Cell Lymphomas (CTCL). Front. Oncol. 2019, 9, 429. [CrossRef]

60. Gantchev, J.; Martinez Villarreal, A.; Gunn, S.; Zetka, M.; Odum, N.; Litvinov, I.V. The ectopic expression of meiCT genes promotes meiomitosis and may facilitate carcinogenesis. Cell Cycle 2020, 19, 837-854. [CrossRef]

61. Litvinov, I.V.; Kupper, T.S.; Sasseville, D. The role of AHI1 and CDKN1C in cutaneous T-cell lymphoma progression. Exp. Derm. 2012, 21,964-966. [CrossRef] [PubMed]

62. Litvinov, I.V.; Zhou, Y.; Kupper, T.S.; Sasseville, D. Loss of BCL7A expression correlates with poor disease prognosis in patients with early-stage cutaneous T-cell lymphoma. Leuk. Lymphoma 2013, 54, 653-654. [CrossRef] [PubMed]

63. Lindahl, L.M.; Willerslev-Olsen, A.; Gjerdrum, L.M.R.; Nielsen, P.R.; Blumel, E.; Rittig, A.H.; Celis, P.; Herpers, B.; Becker, J.C.; Stausbol-Gron, B.; et al. Antibiotics inhibit tumor and disease activity in cutaneous T-cell lymphoma. Blood 2019, 134, 1072-1083. [CrossRef]

64. Wu, C.S.; Lan, C.C.; Chiou, M.H.; Yu, H.S. Basic fibroblast growth factor promotes melanocyte migration via increased expression of p125(FAK) on melanocytes. Acta Derm. Venereol. 2006, 86, 498-502. [CrossRef] [PubMed]

65. Singh, Z.N.; Tretiakova, M.S.; Shea, C.R.; Petronic-Rosic, V.M. Decreased CD117 expression in hypopigmented mycosis fungoides correlates with hypomelanosis: Lessons learned from vitiligo. Mod. Pathol. 2006, 19, 1255-1260. [CrossRef]

66. Wankowicz-Kalinska, A.; van den Wijngaard, R.M.; Tigges, B.J.; Westerhof, W.; Ogg, G.S.; Cerundolo, V.; Storkus, W.J.; Das, P.K. Immunopolarization of CD4+ and CD8+ T cells to Type-1-like is associated with melanocyte loss in human vitiligo. Lab. Invest. 2003, 83, 683-695. [CrossRef]

67. Herrmann, J.L.; Syklawer, E.; Tarrillion, M.; Duvic, M.; Hughey, L.C. Concomitant mycosis fungoides and vitiligo: How mycosis fungoides may contribute to melanocyte destruction. Dermatology 2015, 230, 143-149. [CrossRef]

68. Rodrigues, M. Skin Cancer Risk (Nonmelanoma Skin Cancers/Melanoma) in Vitiligo Patients. Derm. Clin. 2017, 35, 129-134. [CrossRef]

69. Paulson, K.G.; Lahman, M.C.; Chapuis, A.G.; Brownell, I. Immunotherapy for skin cancer. Int. Immunol. 2019, 31, 465-475. [CrossRef]

70. Larsabal, M.; Marti, A.; Jacquemin, C.; Rambert, J.; Thiolat, D.; Dousset, L.; Taieb, A.; Dutriaux, C.; Prey, S.; Boniface, K.; et al. Vitiligo-like lesions occurring in patients receiving anti-programmed cell death-1 therapies are clinically and biologically distinct from vitiligo. J. Am. Acad. Derm. 2017, 76, 863-870. [CrossRef]

71. Hua, C.; Boussemart, L.; Mateus, C.; Routier, E.; Boutros, C.; Cazenave, H.; Viollet, R.; Thomas, M.; Roy, S.; Benannoune, N.; et al. Association of Vitiligo With Tumor Response in Patients With Metastatic Melanoma Treated With Pembrolizumab. JAMA Derm. 2016, 152, 45-51. [CrossRef]

72. Ouwerkerk, W.; van den Berg, M.; van der Niet, S.; Limpens, J.; Luiten, R.M. Biomarkers, measured during therapy, for response of melanoma patients to immune checkpoint inhibitors: A systematic review. Melanoma Res. 2019, 29, 453-464. [CrossRef] [PubMed]

73. Liu, R.C.; Consuegra, G.; Chou, S.; Fernandez Penas, P. Vitiligo-like depigmentation in oncology patients treated with immunotherapies for nonmelanoma metastatic cancers. Clin. Exp. Derm. 2019, 44, 643-646. [CrossRef] [PubMed]

74. Yazganoglu, K.D.; Topkarci, Z.; Buyukbabani, N.; Baykal, C. Childhood mycosis fungoides: A report of 20 cases from Turkey. J. Eur. Acad. Derm. Venereol. 2013, 27, 295-300. [CrossRef] [PubMed]

75. Wain, E.M.; Orchard, G.E.; Whittaker, S.J.; Spittle, M.S.M.F.; Russell-Jones, R. Outcome in 34 patients with juvenile-onset mycosis fungoides: A clinical, immunophenotypic, and molecular study. Cancer 2003, 98, 2282-2290. [CrossRef] [PubMed]

76. Cervini, A.B.; Torres-Huamani, A.N.; Sanchez-La-Rosa, C.; Galluzzo, L.; Solernou, V.; Digiorge, J.; Rubio, P. Mycosis Fungoides: Experience in a Pediatric Hospital. Actas Dermosifiliogr. 2017, 108, 564-570. [CrossRef]

77. Simon, A.K.; Hollander, G.A.; McMichael, A. Evolution of the immune system in humans from infancy to old age. Proc. Biol. Sci. 2015, 282, 20143085. [CrossRef]

78. Derhovanessian, E.; Solana, R.; Larbi, A.; Pawelec, G. Immunity, ageing and cancer. Immun. Ageing 2008, 5, 11. [CrossRef] 
79. Sigal, M.; Grossin, M.; Laroche, L.; Basset, F.; Aitken, G.; Haziza, J.L.; Belaich, S. Hypopigmented mycosis fungoides. Clin. Exp. Derm. 1987, 12, 453-454. [CrossRef]

80. Stone, M.L.; Styles, A.R.; Cockerell, C.J.; Pandya, A.G. Hypopigmented mycosis fungoides: A report of 7 cases and review of the literature. Cutis 2001, 67, 133-138.

81. Pradhan, D.; Jedrych, J.J.; Ho, J.; Akilov, O.E. Hypopigmented Mycosis Fungoides with Large Cell Transformation in a Child. Pediatr. Dermatol. 2017, 34, e260-e264. [CrossRef] [PubMed]

82. Geller, S.; Lebowitz, E.; Pulitzer, M.P.; Horwitz, S.M.; Moskowitz, A.J.; Dusza, S.; Myskowski, P.L. Outcomes and prognostic factors in African American and black patients with mycosis fungoides/Sezary syndrome: Retrospective analysis of 157 patients from a referral cancer center. J. Am. Acad. Dermatol. 2019. [CrossRef] [PubMed]

83. Furlan, F.C.; Pereira, B.A.; Sotto, M.N.; Sanches, J.A. Hypopigmented mycosis fungoides versus mycosis fungoides with concomitant hypopigmented lesions: Same disease or different variants of mycosis fungoides? Dermatology 2014, 229, 271-274. [CrossRef] [PubMed]

84. Lambroza, E.; Cohen, S.R.; Phelps, R.; Lebwohl, M.; Braverman, I.M.; DiCostanzo, D. Hypopigmented variant of mycosis fungoides: Demography, histopathology, and treatment of seven cases. J. Am. Acad. Derm. 1995, 32, 987-993. [CrossRef]

85. Moulonguet, I.; Robert, C.; Baudot, N.; Flageul, B.; Dubertret, L. Hypopigmented mycosis fungoides in a light-skinned woman. Br. J. Derm. 1998, 139, 341-343. [CrossRef]

86. Grunwald, M.H.; Amichai, B. Localized hypopigmented mycosis fungoides in a 12-year-old caucasian boy. J. Derm. 1999, 26, 70-71. [CrossRef]

87. Quaglino, P.; Zaccagna, A.; Verrone, A.; Dardano, F.; Bernengo, M.G. Mycosis fungoides in patients under 20 years of age: Report of 7 cases, review of the literature and study of the clinical course. Dermatology 1999, 199, 8-14. [CrossRef]

88. Qari, M.S.; Li, N.; Demierre, M.F. Hypopigmented mycosis fungoides: Case reports and literature review. J. Cutan Med. Surg. 2000, 4, 142-148. [CrossRef]

89. Gulekon, A.; Ozsoy, E.; Gurer, M.A.; Ataoglu, O. Hypopigmented mycosis fungoides in an adolescent Turkish boy. Int. J. Derm. 2005, 44, 795-796. [CrossRef]

90. Hodak, E.; Klein, T.; Gabay, B.; Ben-Amitai, D.; Bergman, R.; Gdalevich, M.; Feinmesser, M.; Maron, L.; David, M. Familial mycosis fungoides: Report of 6 kindreds and a study of the HLA system. J. Am. Acad. Derm. 2005, 52, 393-402. [CrossRef]

91. Wain, E.M.; Orchard, G.E.; Mayou, S.; Atherton, D.J.; Misch, K.J.; Russell-Jones, R. Mycosis fungoides with a CD56+ immunophenotype. J. Am. Acad. Derm. 2005, 53, 158-163. [CrossRef]

92. Onsun, N.; Kural, Y.; Su, O.; Demirkesen, C.; Buyukbabani, N. Hypopigmented mycosis fungoides associated with atopy in two children. Pediatr. Derm. 2006, 23, 493-496. [CrossRef] [PubMed]

93. Grover, S.; Verma, R.; Mani, N.S.; Grewal, R.S.; Singh, G.K. Primary Cutaneous T-cell Lymphoma: Two Rare Presentations. Med. J. Armed Forces India 2010, 66, 73-75. [CrossRef]

94. Koorse, S.; Tirumalae, R.; Yeliur, I.K.; Jayaseelan, E. Clinicopathologic profile of hypopigmented mycosis fungoides in India. Am. J. Derm. 2012, 34, 161-164. [CrossRef] [PubMed]

95. Hassab-El-Naby, H.M.; El-Khalawany, M.A. Hypopigmented mycosis fungoides in Egyptian patients. J. Cutan. Pathol. 2013, 40, 397-404. [CrossRef] [PubMed]

96. Zhang, J.A.; Yu, J.B. Hypopigmented mycosis fungoides in a chinese woman. Indian J. Dermatol. 2013, 58, 161. [CrossRef]

97. Alhumidi, A.A. Hypopigmented mycosis fungoides in Saudi Arabia, epidemiological and pathological study. J. Dermatol. Dermatol. Surg. 2014, 18, 8-12. [CrossRef]

98. Boulos, S.; Vaid, R.; Aladily, T.N.; Ivan, D.S.; Talpur, R.; Duvic, M. Clinical presentation, immunopathology, and treatment of juvenile-onset mycosis fungoides: A case series of 34 patients. J. Am. Acad. Derm. 2014, 71, 1117-1126. [CrossRef]

99. Abdel-Halim, M.; El-Nabarawy, E.; El Nemr, R.; Hassan, A.M. Frequency of hypopigmented mycosis fungoides in Egyptian patients presenting with hypopigmented lesions of the trunk. Am. J. Derm. 2015, 37, 834-840. [CrossRef]

100. Mateeva, V.; Kadurina, M. Clinical, Histological and Immunohistochemical Changes in Hypopigmented Mycosis Fungoides in Response to Narrow-Band UVB Phototherapy. J. Pigment. Disord. 2015, 2. [CrossRef] 
101. Joseph, M.X.; Brown, A.D.; Davis, L.S. The importance of lymph node examination: Simultaneous diagnosis of hypopigmented mycosis fungoides and follicular B-cell lymphoma. Jaad Case Rep. 2018, 4, 590-592. [CrossRef] [PubMed]

102. Vilas Boas, P.; Hernandez-Aragues, I.; Suarez-Fernandez, R.; Campos-Dominguez, M. Hypopigmented patches on the buttocks of a 7-year-old boy. Clin. Exp. Derm. 2018, 43, 485-487. [CrossRef] [PubMed]

103. Landgrave-Gomez, I.; Ruiz-Arriaga, L.F.; Toussaint-Caire, S.; Vega-Memije, M.E.; Lacy-Niebla, R.M. Epidemiological, clinical, histological, and immunohistochemical study on hypopigmented epitheliotropic T-cell dyscrasia and hypopigmented mycosis fungoides. Int. J. Dermatol 2019. [CrossRef] [PubMed]

104. el-Hoshy, K.; Hashimoto, K. Adolescence mycosis fungoides: An unusual presentation with hypopigmentation. J. Derm. 1995, 22, 424-427. [CrossRef]

105. Ben-Amitai, D.; Michael, D.; Feinmesser, M.; Hodak, E. Juvenile mycosis fungoides diagnosed before 18 years of age. Acta Derm. Venereol. 2003, 83, 451-456. [CrossRef] [PubMed]

106. Hsiao, P.F.; Hsiao, C.H.; Tsai, T.F.; Jee, S.H. Minimal residual disease in hypopigmented mycosis fungoides. J. Am. Acad. Dermatol. 2006, 54, S198-S201. [CrossRef]

107. Ozcan, D.; Seckin, D.; Ozdemir, B.H. Hypopigmented macules in an adult male patient. Clin. Exp. Derm. 2008, 33, 667-668. [CrossRef]

108. Cho-Vega, J.H.; Tschen, J.A.; Duvic, M.; Vega, F. Early-stage mycosis fungoides variants: Case-based review. Ann. Diagn. Pathol. 2010, 14, 369-385. [CrossRef]

109. Nanda, A.; AlSaleh, Q.A.; Al-Ajmi, H.; Al-Sabah, H.; Elkashlan, M.; Al-Shemmari, S.; Demierre, M.F. Mycosis fungoides in Arab children and adolescents: A report of 36 patients from Kuwait. Pediatr. Derm. 2010, 27, 607-613. [CrossRef]

110. Khopkar, U.; Doshi, B.R.; Dongre, A.M.; Gujral, S. A study of clinicopathologic profile of 15 cases of hypopigmented mycosis fungoides. Indian J. Dermatol. Venereol. Leprol. 2011, 77, 167-173. [CrossRef]

111. Rizzo, F.A.; Vilar, E.G.; Pantaleao, L.; Fonseca, E.C.; Magrin, P.F.; Henrique-Xavier, M.; Rochael, M.C. [Mycosis fungoides in children and adolescents: A report of six cases with predominantly hypopigmentation, along with a literature review]. Derm. Online J. 2012, 18, 5.

112. Uhlenhake, E.E.; Mehregan, D.M. Annular hypopigmented mycosis fungoides: A novel ringed variant. J. Cutan. Pathol. 2012, 39, 535-539. [CrossRef] [PubMed]

113. Wongpraparut, C.; Setabutra, P. Phototherapy for hypopigmented mycosis fungoides in Asians. Photodermatol. Photoimmunol. Photomed. 2012, 28, 181-186. [CrossRef] [PubMed]

114. Gameiro, A.; Gouveia, M.; Tellechea, O.; Moreno, A. Childhood hypopigmented mycosis fungoides: A commonly delayed diagnosis. BMJ Case Rep. 2014. [CrossRef]

115. Heng, Y.K.; Koh, M.J.; Giam, Y.C.; Tang, M.B.; Chong, W.S.; Tan, S.H. Pediatric mycosis fungoides in Singapore: A series of 46 children. Pediatr. Derm. 2014, 31, 477-482. [CrossRef] [PubMed]

116. Fatemi Naeini, F.; Abtahi-Naeini, B.; Sadeghiyan, H.; Nilforoushzadeh, M.A.; Najafian, J.; Pourazizi, M. Mycosis fungoides in Iranian population: An epidemiological and clinicopathological study. J. Ski. Cancer 2015, 306543. [CrossRef] [PubMed]

117. Naeini, F.F.; Soghrati, M.; Abtahi-Naeini, B.; Najafian, J.; Rajabi, P. Co-existence of various clinical and histopathological features of mycosis fungoides in a young female. Indian J. Dermatol. 2015, 60, 214. [CrossRef]

118. Ichimura, Y.; Sugaya, M.; Morimura, S.; Suga, H.; Sato, S.; Mori, S.; Takahashi, H.; Akutsu, Y. Two cases of CD8-positive hypopigmented mycosis fungoides without TOX expression. Int J. Dermatol. 2016, 55, e164-e167. [CrossRef]

119. Valencia Ocampo, O.J.; Julio, L.; Zapata, V.; Correa, L.A.; Vasco, C.; Correa, S.; Velasquez-Lopera, M.M. Mycosis Fungoides in Children and Adolescents: A Series of 23 Cases. Actas Dermosifiliogr. 2019. [CrossRef]

120. Kalay Yildizhan, I.; Sanli, H.; Akay, B.N.; Surgun, E.; Heper, A. CD8(+) cytotoxic mycosis fungoides: A retrospective analysis of clinical features and follow-up results of 29 patients. Int J. Derm. 2020, 59, 127-133. [CrossRef]

(C) 2020 by the authors. Licensee MDPI, Basel, Switzerland. This article is an open access article distributed under the terms and conditions of the Creative Commons Attribution (CC BY) license (http://creativecommons.org/licenses/by/4.0/). 